\title{
Reframing bi-nationalism in Palestine-Israel as a process of settler decolonisation
}

\begin{abstract}
This paper examines some of the emerging critical civil society debates in relation to the one-state solution being the most appropriate geo-political arrangement for the articulation of freedom, justice and equality in Palestine-Israel. This is done with reference to the Israeli Committee Against House Demolitions' (ICAHD) 2012 statement in support of a bi-national state and the ensuing critiques it attracted from Palestinian supporters of the onestate position. Drawing on these debates which have largely revolved around Jewish Israeli rights to political self-determination in Palestine-Israel, this paper proposes that alternative versions of self-determination as cultural rights for the established Hebrew-speaking national community represents a more inclusive form of self-determination in the eventuality of decolonisation.
\end{abstract}

Key words: bi-nationalism, critical activism, decolonisation, Palestine-Israel, one-state, selfdetermination

\section{Introduction}

In the past two decades, largely due to disillusionment with the Oslo Peace Process, debates and discussions surrounding a one-state alternative to the impasse in Palestine-Israel have been gaining momentum among Palestinian activists and thinkers, as wells as a growing number of critical Israelis and international observers, including a number of contributors to Antipode (Abunimah, 2006; Bisherat, 2010; Farsakh, 2011; Hilal, 2007; Loewenstein and Moor, 2012; Long, 2006; Mavroudi, 2010; Raz-Krakotzkin, 2011; Said, 2006; Tilley, 2005). These debates have largely arisen in response to the failure of the official peace process, the outbreak of the second intifada, and the subsequent 2005 Palestinian civil society call for Boycotts, Divestment and Sanctions (BDS) against Israel until the end of 
occupation/colonisation of Arab lands, the return of the Palestinian refugees expelled in 1948 and 1967, and equal rights for Palestinian citizens in Israel.

The call for Boycotts, Divestment and Sanctions is supported by a small though growing number of critical Israeli groups and individuals including the signatories of Boycott from Within, Anarchists Against the Wall (AATW), the Israeli Committee Against House Demolitions (ICAHD), Zochrot, and the Coalition of Women for Peace, an umbrella organisation of anti-militarist, feminist women's groups. The concept 'critical' here refers to those individuals and organisations who (a) acknowledge that the Jewish Israeli side is the dominant and stronger one in the conflict, leading to (b) a rejection of uncritical militarist and pro-state approaches; and (c) a declaration that any discussion about and potential solution to the conflict can only progress by addressing and incorporating the Palestinian narrative. Critical Israeli groups are further differentiated from traditional Left peace groups. The latter prefer negotiation-style interfaith dialogue groups; while the former emphasise practical solidarity and co-resistance, as well as, seek to articulate a radically new and different way of thinking about intercultural cohabitation in Palestine-Israel.

In recent years, these critical Israeli voices have converged with Palestinian calls for decolonisation, and demands for Israel to become 'a state for all its citizens'. More recently these discussions have also been accompanied by a greater emphasis on, and debate over, the possibility of cohabitation in a single and/or bi-national state in Palestine-Israel. This in turn has placed emphasis on solidarity and 'joint-struggle' for decolonisation and democratisation. However, the growing move towards advocacy of egalitarian cohabitation in a shared geopolitical space is not free of contradictions and tensions. Accepting the label of 'colonisers' has been difficult for critical Israelis. Similarly, accepting the possibility of decolonisation, resulting not only in an end to Jewish privilege in Palestine-Israel, but more so the possibility of impending minoritarian status in a future Arab-Palestinian majority state, in the case of a 
full or partial return, is similarly experienced as problematic and undesirable. In this sense, support for a one-state solution is not a singular or unified vision. In many respects there are as many visions as visionaries. It is for this reason, for example, that Jeff Halper (2012), ICAHD's founder, argues in favour of a bi-national state as a precondition for cohabitation, while Zochrot's reflections on the Palestinian refugee return envisage a loose federation of autonomous cultural collectivities coexisting in a future decolonised Palestine-Israel (Musih and Bronstein, 2010).

This article's contribution to these ongoing debates is to suggest a rethinking of the relationship between the 'Jewish' and 'Israeli' components of the Jewish-Israeli identity, beginning with an acknowledgement of the role of 'Jewishness' in the Zionist settler-colonial project and its continuing deployment to justify Jewish diasporic settler-colonialism, while denying the rights of return of the Palestinian refugee Diaspora. Thus, a rearticulation of Jewish-Israeliness as a civic, cultural and linguistic community might better serve to break with settler-colonial privilege, while acknowledging and affirming the specificity and history of Hebrew cultural life in Palestine-Israel. In order to articulate some of the ongoing tensions in the above debates on self-determination in a unified Palestine-Israel, and suggest potential avenues for reconciliation in the process of decolonisation, this paper utilises the 'all affected' principle.

The principle, as defined by Fraser (1997), stipulates that just political action in a transnational world must not rely on the geo-political boundaries of states and their legal jurisdiction, but rather on addressing injustices against those who have been affected by a given institution, whether a state or corporation, irrespective of the official membership or belonging of those affected to the said institution. In the context of cohabitation in PalestineIsrael, this means that Palestinian refugees outside Israel and the Occupied Territories, as well as disenfranchised Palestinians in the Occupied Territories, are considered subjects of 
justice in relation to the Israeli state and its citizens, in as far as the Israeli state continues to affect their lives and denies the actualisation of their rights to return and to equal citizenship.

In line with further elaboration of the principle by Iris Marion Young (2007) into a commitment to collective responsibility for justice, the 'all-affected' principle should not be seen as only applying to historic and/or ongoing injustice, but rather as a process which needs to be incorporated into thinking about future solutions and visions for cohabitation. This would include addressing the potential, in the case of anti-colonial and/or anti-settlerist struggle, to reinforce dichotomous ethno-nationalist positions and in the process refuse the possibility of the decolonisation of former colonisers (see also Svirsky, 2014b). As such, the 'all affected' principle takes as its starting position a critique of unequal power relations, while affirming the view that power is not static and does not belong to any given group for posterity.

In light of the above, this paper seeks to address the concerns and rights of the excluded Palestinian diaspora, but also of Jewish Israelis who might wish to remain in a future decolonised Palestine-Israel. However, the principle as thus understood, excludes the nonIsraeli Jewish diaspora as, it is argued, its claim to right in Palestine-Israel can only be accepted if a right to settler-colonialism is affirmed, and this paper rejects such a right as ethically indefensible. Hence, the term 'Palestine-Israel' (or 'Israel-Palestine') underscores the two competing narratives laying claim in/to the land of Historic Palestine (pre-1948), the state of Israel (post-1948), and the Occupied Palestinian Territories of the Gaza Strip and West Bank (post-1967), and alludes to their possible reconciliation as envisaged by contemporary thinkers and critical civil society groups working towards a just peace in Palestine-Israel. 
The account that follows is in no way a map, a blueprint, or a prescription for co-existence. The paper's primary concern is rather to examine some of the emerging civil society debates that have arisen primarily in response to the demands of the BDS movement in relation to growing advocacy for a one-state solution as the most appropriate geo-political arrangement for the articulation of justice and equality in Palestine-Israel. This is done with reference to ICAHD's 2012 statement in support of a bi-national state and ensuing critiques by Palestinian supporters of the one-state position. However, it should be stressed that the BDS movement does not currently hold an official position on any state solution, and as such many of these debates are primarily explorative rather than prescriptive in nature. On the whole, these onestate debates start from a rejection of the settler-colonial policies and practices of the contemporary Israeli state, accepting as a given the collective and as yet unactualised Palestinian right to self-determination in Palestine-Israel, and further seek to address the three key demands of the Palestinian civil society's call for freedom, justice and equality in Palestine-Israel.

\section{Decolonising Palestine-Israel}

Before proceeding to discuss contemporary civil society attempts to reframe dominant formulations of the conflict and its possible bi-national resolution, a number of terms require clarification. Thus far, Israel and its geo-political policies have been described as 'settlercolonial'. This is a disputed concept for some (see Aharonson, 1996; Mansdorf, 2010); however, the term is in wide usage by a majority of respected scholars working on the region (Elkin and Pedersen, 2005; Goldstein and Lubin, 2008; Gregory, 2004a; Lloyd, 2012; Pappe, 2008; Piterberg, 2010; Shafir, 2005; Stasiulis and Yuval-Davis, 1995; Svirsky, 2010, 2014; Veracini 2007, 2010). In particular, this paper draws on the work of Veracini, who stresses the separate and distinct nature of settler-colonialism in general, and in relation to Israel in particular which, he argues, sets it apart from both colonialism and immigration. In the case 
of the former, he defines colonisation as a conquered polity dominated by an 'exogenous agency'; whereas migration, while sharing the aspect of displacement with settlement, is different from it in that migrants arrive and are expected to assimilate into a pre-existing and constituted political order. Settlement, on the other hand, is characterised by conquest, 'return', and an ingathering in a place in which the settler collectivity institutes a new sovereign order where they come to be in control of both the usurped/displaced indigenouspopulation, and exogenous others such as enslaved Africans in the United States or contemporary immigrants (Veracini, 2010: 3-12).

Thus, while most Israelis do not see themselves as settler-colonists, particularly in the case of Mizrahi migrants who arrived in the 1950s after the establishment of the state, or the more recent émigrés from Eastern Europe and elsewhere, Israel as a nation-state project nonetheless bares the hallmarks of a settler-colonial enterprise. This is particularly evident in state narratives that are dominated by disavowal, one of the key characteristic of settler psychology. This includes the disavowal of any responsibility or complicity in colonialism in Israel's case colonialism is something associated with the British Empire, not Jewish settlers; denial of any founding violence against the indigenous population - 'they just left'; and emphasis on settler innocence and suffering - 'seeking refuge from persecution' (Piterberg, 1996, 2001, 2008, 2010).

Disavowal is further coupled with an emphasis on settler struggle, and outstanding contribution to the land, together with an appropriation of authentic indigeneity - 'return to the promised land', 'making the desert bloom', and/or 'a land without a people, for a people without a land' (see Piterberg, 2001, 2008, 2010). Indeed, such narrative tropes have played a crucial role in securing Israel's settler-colonial project, from the consolidation of early Jewish settlement in Palestine and the establishment of the state of Israel (Pappe, 2006 and 2011), to the present maintenance of the ongoing oppressive tripartite regime in Israel, the West Bank 
and the Gaza Strip (Azoulay and Ophir, 2012), as well as the denial of the $\mathrm{Nakba}^{\mathrm{i}}$ and the Palestinian refugees' right of return (Pappe, 2006; Peled-Elhanan, 2012).

Ongoing settler colonisation is also strikingly evident in the geo-political policies and practices of the Israeli state and its bureaucracy, particularly in the West Bank, but also in Israel within its 1948 borders. An example of the latter is the official and unofficial 'Judaization' planning and resettlement policies in force in the Galilee since the 1980s, and the ongoing expulsions of the Bedouin Palestinians in the Negev/Naqab, the latter closely mirroring land expropriation in the West Bank. The ongoing colonisation of the West Bank is particularly hard to ignore. The settlements in annexed and occupied East Jerusalem and the West Bank are illegal under International Law ${ }^{\text {ii }}$. Judea and Samaria, as the Israeli government officially refers to the territory of the West Bank in its internal communication and military orders, is alleged 'disputed' territory, i.e. the Palestinians claim it is land for their future state, but Israel also claims it as her sovereign territory.

The half a million Israeli settler-colonists who reside in East Jerusalem and the West Bank are linked to Israel 'proper' through a complex and exclusive grid of roads to which Palestinians are denied access. It is possible to drive from the settler colony of Ma'ale Adumim to Tel Aviv and back without ever being given any indication that you have left Israel or entered the occupied West Bank at any point. Palestinians, on the other hand, might live in a West Bank village half of which is on the other side of the Separation Wall, where they have no legal permission to enter or visit. This obfuscated and perplexing set-up was largely made possible by the geo-political arrangement put into place as a result of the Oslo Accords, and the emergence of Areas A, B, and C; an arrangement which absolved Israel from responsibility as an Occupying Power towards the Palestinian civilians under its control, and gave the military-run Civil Administration unprecedented and internationally-sanctioned 
control of most of the physical land of the West Bank (Abu Zahra, 2008; Gregory, 2004a; Hanafi, 2009; Weizman, 2007).

Alongside disavowal and geo-political practices of displacement and resettlement, a further characteristic of settler-colonialism is the elimination and/or physical or narrative replacement of the indigenous population by the settler collectivity (Wolfe, 1999, 2006; Veracini, 2007, 2010). In fact, one distinguishing aspect separating pure colonialism from settler-colonialism is precisely the issue of 'labour versus land'. In pure colonialism, the exogenous rulers rely on and expect servitude by, indigenous labourers, often having colonised precisely for the purpose of extracting resources and labour for the benefit of the Metropole and its representatives. On the other hand, while not always achievable in reality, settler colonies aspire to independence and self-sufficiency, and seek to become the natives of the land.

As Shafir (2005) highlights, early Jewish settlement in Palestine was initially modelled on other colonial entities such as French Algeria. However, during the subsequent settler waves of migration a strong emphasis on self-reliance and Jewish-only labour became the dominant demand. The difficulty of maintaining a Jewish-only labour force during pre-state settlement, partly because of the small number of Jewish workers at this stage, but also due to lack of agricultural and other skills among the Yishuv population, in contrast to the plentiful and cheaper labour provided by Palestinian agricultural workers, resulted in mass discontent and union strikes by the settler population (Shafir, 2005: 44-55). In the years after the state was established, and as a result of the large-scale ethnic cleansing of the indigenous Arab Palestinian population, the above settler-only model became the dominant mode of organisation, particularly in the early years of state formation. However, it was more prominently re-established in the 1990s through the policy of 'closure' vis-à-vis the Occupied Territories. Closure has only been possible with the arrival of large numbers of cheap migrant 
labour from Asia, Africa, and Eastern Europe to replace the cheap labour previously supplied by the occupied Palestinians (Klein, 2007).

The settler-colonial sovereign ability to control the population economy comprised of settler colonists, indigenous and exogenous others, has meant that the presence of exogenous others does not challenge the settler-colonial paradigm but can rather be co-opted to bolster settler supremacy in relation to the indigenous population. A similar example, though one with far worse consequences for the indigenous population, is the case of the United States where the indigenous First Nations were eliminated almost in their entirety to be replaced by claims to settler indigeneity (Smith, 2010). Thus, with the elimination of most of the indigenous population of North America, the European settler-colonists have been able to institute themselves as the original and authentic inhabitants and hence to maintain their right to govern in relation to later arrivals. Moreover, the virtual elimination of the indigenous population has also meant that the settler polity has had, over time, to rely on importing racialised exogenous labour in order to develop the colonial enterprise. In the pre-state period these needs were met by the labour of enslaved Africans, and indentured African-Americans, post-emancipation. Today other racialised exogenous workers such as migrant labourers from South America fulfil this role (Smith, 2010; Walia 2013).

In this respect, one of the biggest obstacles to decolonising settler-colonialism continues to be the dominance of the elimination or zero-sum paradigm ${ }^{\mathrm{iii}}$, in which any future remodelling of a settler-colonial society, often as a result of struggles for recognition by exogenous others, takes place within the established settler-colonial order: for example, civil rights for African Americans in the United States. Conversely, even in cases where there has not been a physical elimination of the indigenous population, decolonisation has often been characterised by the flight of the European settlers, for example in Algeria or Rhodesia/Zimbabwe (Veracini, 2007). Nevertheless, there are also other less bleak examples 
in which settler decolonisation is an ongoing process rather than a clean and brutal break with the past, such as in post-Apartheid South Africa but also the often neglected case of many South American countries where the European settler-colonial population has by and large assimilated into the indigenous population, further mixing with exogenous others, and creating a majority mestizo (mixed) population. Thus, while settler decolonisation or discontinuity remains a problematic task, it is nevertheless not an impossible one.

\section{Bi-nationalism as a process of Decolonisation}

Indeed, the Palestinian call for Boycotts, Divestment and Sanctions (BDS) against Israel is partially modelled on the South African anti-Apartheid struggle which, despite its limitations continues to be one of the most successful decolonisation struggles related to a settlercolonial society. Two hallmark achievements of the BDS movement have been the critical reframing of the impasse in Palestine-Israel as a civil rights struggle for freedom, justice and equality, away from the emphasis on national liberation embodied in the logic of the twostate paradigm; and the rearticulation of Palestinian-Israeli civil society relations away from co-existence forums, which imply parity and symmetry between participants, to one of coresistance against colonisation and dispossession (see Svirsky, 2010, 2014).

However, the demands of the BDS call have been criticised by sympathisers and opponents alike, for their lack of clarity with regards to their stated goals, which have the potential to exclude Israeli Jews (Kamel, 2014), and even for a presumed underhand desire to ‘deligitimise' and/or 'destroy’ Israel (see Karsh, ed., 2012, Israel Affairs, Special Issue Vol. 18). The latter charge in particular relates to a tendency to state Israel's right to self-define as and remain an exclusive 'Jewish' state, with its potential evolution into a multicultural and democratic state for all its citizens being viewed as dangerous and destructive. However, this particular perspective stems from an uncritical assumption that states have rights which 
supersede those of their citizens. As Joan Cocks writes, the debate is not really about whether Israel does or does not have a right to exist but rather that 'existence rights logically do not apply to states. People can be said to have prima facie existence rights, may claim they need a state of their own to protect them. It is only once we make this conceptual distinction that we can critically assess the cogency of that claim' (2006: 25, footnote 1, original emphasis). In relation to this, this paper adopts a stand-point which, in its ethical-political commitment to justice and equality, views the state as a conveyor for the actualisation and security of the rights of all its citizens and residents. Hence, it is the prerogative of citizens and residents to define, in the final instance, what their state should look like. Correspondingly, a state that insists on defining its citizen body in its image and according to its political doctrine is exclusionary and undemocratic in nature and must be reframed and rearticulated as just and egalitarian $^{\text {iv }}$.

A further criticism of the implications of the BDS call for Palestine-Israel is often articulated in terms of support and commitment for the ethno-centric two-state solution as more practical and legitimate (Hermann, 2005). What does the two-state solution mean in practical terms? Critics of one-state positions often dismiss these as unrealistic intellectual and/or elite visions. Yet, the parameters of the two-state solution remain disputed. The 1947 UN Partition plan failed as a result of the 1948 War. The 1990s Oslo Accords, often seen as a historic compromise during which Israel acknowledged the Palestinians, and the Palestinians reconciled themselves to Israel's presence in Palestine/Israel, never stipulated or outlined a final two-state solution (Khalidi, 1997 and 2006). The widely-held notion that the two-state solution would be based on the 1967 occupation borders of the Gaza Strip and West Bank relies on an interpretation of UN Resolution 242 (1967), which the Oslo Accords largely ignored, relegating the issue of borders to an ever-impending final status negotiation. Moreover, although the Resolution calls for Israel to withdraw from occupied lands, there is 
no mention of a Palestinian state, only respect for 'recognised [state] boundaries' (Article 1.ii).

The 2012 UN General Assembly vote to recognise the 1967 Occupied Territories as an independent Palestinian State was rejected by Israel and the United States, and remains so at the time of writing (see Aljazeera Middle East, 2012; Tharoor, 2014). Coupled with continuing occupation and ongoing settler-colonial expansion in the West Bank and Gaza, the widely propagated two-state solution's borders remain just as malleable as any other alternative position. Indeed, under the implied promise of the establishment of a Palestinian state, roughly coinciding with the 1967 border, and permitting Israel to demand 'land-swaps' for its ever expanding colonial settlements, the Oslo Accords codified further annexation and the physical separation between the West Bank and Gaza, and within the West Bank itself.

In 2014, Israel controls all of Gaza's borders (including indirectly its Rafah border-crossing to Egypt), as well as its territorial waters and airspace, and is in full control of $74 \%$ of land in the West Bank, leaving the Palestinian Authority, established by the Oslo Accords, in charge of the Palestinian civilian population in roughly $26 \%$ of the West Bank, and in security control of a mere 3\% (see also Abu Zahra, 2008; Ghanim, 2008; Gregory, 2004; Hanafi, 2009; Gordon, N, 2008; Weizman, 2007, 2011). This geo-political reality does not, of course, make the two-state solution impossible, even if for all practical purposes it appears improbable. However, given the current impasse, growing civil society considerations of onestate alternatives are not any more elitist or unrealistic than the improbable proclamations of governmental elites who espouse support for two states while ignoring the fact that at present only one side has the power to make any sort of state possible.

Therefore, a discussion of any state scenario needs to begin with an acknowledgement that the Israeli-Palestinian impasse is a struggle between two deeply unequal sides: one a settler- 
colonial nation-state with constantly shifting, yet internationally recognised sovereign and respected borders, and the other a colonised and dispossessed population dispersed across the region and elsewhere. This power disparity is perhaps most clearly articulated in the tactics of Israel and the Palestinians. Since 1948, Israel has for the most part, been able to make unilateral decisions to change the geo-political landscape of Palestine-Israel, including but not limited to population transfer, renaming and rezoning of land, military and civilian occupation, and the building and expansion of internationally unrecognised settler colonies in Gaza until 2006, and presently in the West Bank (Abu Zahra, 2008; Eldar and Zertal, 2007; Ghanim, 2008; Gordon, N., 2008; Gregory, 2004a; Hanafi, 2009; Pappe, 2006, 2011; Weizman, 2007, 2011).

On the other hand, as a stateless people, the Palestinians have largely relied on the mercy of inter-governmental consensus, various nonviolent and violent guerrilla tactics, local, national, and international campaigns, and more recently, the transnational BDS campaign for civil rights in Palestine-Israel (Atran, 2010; Barghouti, 2011; Khalidi, 1997, 2006; Said 1984, 1988, 2006; Qumsiyeh, 2010). It is for this reason that examining ongoing civil society debates and visions acts as a means to give voice to the silenced Palestinian narrative and the marginalised voices of critical Israelis who reject dominant state-centric framings of Palestine-Israel. Moreover, growing one-state co-advocacy also suggests possible convergences between Palestinians and critical Israelis; or, to paraphrase Amnon RazKrakotzkin (2011:21), visions of bi-national cohabitation point to the potential decolonisation of Zionism and an alternative Jewish national existence, and de-facto Jewish-Arab cohabitation, in Palestine-Israel. 


\section{Critical Civil Society Responses}

ICAHD, under the auspices of Jeff Halper, is in many respects one of the leading critical Israeli organisations that has spoken out on the subject of a one-state solution for PalestineIsrael; though there are at present as many visions of a one state as there are visionaries. In September 2012, ICAHD, which had previously eschewed adopting a public position on a given state solution, issued a statement officially in support of a one-state solution. Up until the publication of 'In the Name of Justice: Key Issues around a Single State', Jeff Halper had been a strong proponent of what he refers to as a 'Regional Confederation', a concept inspired by the belief that Palestine-Israel is too small a unit to solve all of the key issues concerning the Palestinian refugees' right of return, water, trade, security, borders, and population settlement. Instead, he advocated a regional set-up in which the Occupation of the 1967 territories would be dismantled, a viable and contiguous Palestinian state would be established on all of the 1967 territories, and a regional confederation, similar to the European Union would emerge, comprising Palestine, Israel, Syria, Lebanon, Jordan and possibly Egypt, across which there would be free and unrestricted movement between the territories for the purposes of trade, settlement, and visiting friends and relatives, and whereby the member states would collectively coordinate their security and environmental policy so as to ensure peace and the fair regional distribution of resources such as water (Halper, 2012).

Despite a number of problematic assumptions underlying this proposal, it contributes two important arguments to the discussion on the nature of a possible solution to PalestineIsrael's predicament. Firstly, it underscores the idea that it is possible and desirable for Jewish Israelis to cooperate with and integrate into the region as equal and valuable partners, thus debunking the security pretext for Israel's exceptionalist militarism. Secondly, it responds practically to the potential danger that an implementation of the right of return 
without regional cooperation can lead to the expulsion of those in the Palestinian refugee Diaspora who might in fact wish to remain and settle in their host country rather than physically return to Palestine-Israel. In this respect, a regional confederation could ensure the security and human rights of both individuals and national collectivities in the region. However, underlying the federal proposal is reluctance about the possibility of a full implementation of the Palestinian refugees' right of return which may inevitably lead to a minoritarian status of Jewish Israelis within Palestine-Israel and its myriad implications, notably the possibility of discrimination, oppression and expulsion. This is perhaps one of the key reasons why ICAHD's 2012 statement on a single state places great emphasis on a 'binational' government in Palestine-Israel, governance based on the principle of selfdetermination for Palestinians and Jewish Israelis alike.

ICAHD's statement was welcomed by Palestinian counterparts for accepting PalestinianIsraeli cohabitation in a single state as a desirable resolution, but was nevertheless criticised on key aspects. One of the prime contentions regarding Halper/ICAHD's formulation revolved around the right to national self-determination. Ali Abunimah, a prominent Palestinian Diaspora activist, founder of The Electronic Intifada, an online publication for critical debate and discussion, and author of One Country: A Bold Proposal to End the Israeli-Palestinian Impasse (2006), criticised the ICAHD statement for its underlying implications of bi-nationalism, which granted equal right of self-determination to the JewishIsraeli settler collectivity as that of the displaced and colonised indigenous Palestinians (Abunimah, 2012).

Omar Barghouti (2012), another prominent Palestinian proponent of the one-state solution and a key figure in the BDS movement, also vocally rejected the application of the principle of self-determination to the Jewish collectivity in Palestine-Israel. He further emphasises the fact that the Israeli state does not recognise 'Israeli' or even 'Jewish Israeli' as a nationality. 
Under current Israeli law only 'Jewish' is recognised as a nationality, therefore privileging ongoing transnational Jewish extra-territorial claims to Palestine-Israel (also see Zreik, 2008). The tendency to privilege transnational Jewish claims over the rights of the resident Jewish Israeli collectivity is also underscored by the recent proposal of a Knesset bill intended to redefine Israel as a 'Jewish nation-state' (see Lis, 2014).

As part of his critique of the national question, Barghouti further cites two different international legal definitions pertaining to what constitutes a national collectivity, one of which is the 'Kirby definition', adopted by UNESCO, which stipulates that a people are 'a group of individual human beings who enjoy some or all of the following common features: history, ethnic identity, culture, language, territorial connection etc' (2012: 204). This definition is further extended to include that 'the group as a people must have the will to be identified as a people or the consciousness of being a people' (2012: 204). Barghouti then dismisses both of these definitions as currently inapplicable to Jewish Israelis.

In relation to the bi-national claim he further argues that 'Bi-nationalism, initially espoused by liberal Zionist intellectuals, is premised on a Jewish national right in Palestine, on par, and to be reconciled, with the national right of the indigenous, predominantly Arab population. Bi-nationalism today, despite its many variations, still upholds this ahistorical national right of colonial-settlers' (2012: 198). While Barghouti is correct in asserting that bi-nationalism is not a new or novel proposition, given that variants of it were advocated by Zionist and nonZionist Jewish thinkers in the 1920s and 1930s (see Raz-Krakotzkin, 2011 for a thorough critique of the inherent Orientalism in these early positions), there are nevertheless marked differences between contemporary one-state proposals and the positions supported by previous proponents of a geo-political union in Palestine-Israel. 
These differences are largely due to the very different geo-political reality being described and engaged with in the present. The original Jewish adherents to bi-nationalism such as Gershom Scholem, Martin Buber, and the associated Brit Shalom group, among others, were partly advocating bi-nationalism from a position of weakness. The Zionist settlement project was in its infancy, with Jewish settlement a minoritarian issue, and Palestine under British rule. The current reality is that the Zionist project to settle Palestine and establish a Jewish 'homeland', or at least Jewish domination in the land, has been achieved, and as such Jewish Israeli proponents of bi-nationalism are members of the dominant settler ethno-nation in Palestine-Israel. In other words, the bi-nationalism of Brit Shalom was a bi-nationalism of newcomers trying to establish a foothold in a coveted land. Contemporary Jewish Israeli binationalists depart from this uncritical settlerist logic by conceding their right to exclusive possession of, and domination, over the land. The former can be characterised as a binationalism of settlers; while contemporary positions stem from a commitment to binationalism based on settler decolonisation. This key difference is something that needs to be acknowledged and incorporated into Palestinian considerations of decolonisation and cohabitation.

Moreover, it is important to recognise and engage with the fact that the Israeli state's stubborn refusal to formalise an Israeli nationality ${ }^{\mathrm{v}}$, which is perhaps one of the biggest obstacles to its decolonisation and democratisation, merely testifies to the extra-territorial schemes of the state rather than to a lack of identification among the Jewish Israeli population as a people. For over 60 years, since 1948, Jewish Israelis have shared and been defined by a common language and culture, namely Hebrew. They also share a common territorial identity corresponding to the 1948 borders, with the exception of post-1967 government settlercolonial designs, which have, for the most part, been disputed by a significant number of Israelis. In addition, the most striking example of Jewish-Israeliness is embodied in the 
almost universal willingness to be conscripted and serve in the Israeli Defence Forces (IDF). Even if one is to invoke the fact that many Israelis might speak another language or have family in another country, it would be similar to stating that US nationals, in spite of their settler-colonial past, multicultural and transnational origins, do not constitute a people with a perceived common identity as Americans. Therefore, even if one is to deny or refuse to accept national political self-determination to Jewish Israelis in a shared future state on the basis of their settler-colonial origins, or to insist that they should see themselves as Palestinian Jews, as Uri Davis (2010) argues, it is nevertheless important to acknowledge and engage with the significance of existing national identifications among Israeli Jews in Palestine-Israel.

Ali Abunimah's critique of ICAHD's one-state statement also raises some pertinent objections to the Jewish rights to ongoing and continued settlement in and domination over Palestine-Israel. His key argument is that as members of a settler-colonial nation, JewishIsraelis are not entitled to collective self-determination the way that Palestinians are. This is because the historical-political context in which Jewish Israeli nationalism emerged in Palestine-Israel has only been made possible because of the dispossession of the Palestinian people. Therefore, Jewish Israeli nationhood, which is settler-colonial and exogenous to Palestine, cannot claim self-determination in the manner that the Palestinian people are entitled to by virtue of their indigeneity and their shared collective experience of political discrimination and dispossession.

Abunimah's argument that Israelis are not entitled to a right to national political selfdetermination in Palestine-Israel on the basis that they are not indigenous and, moreover, that their constitution as a nation is based on violent and dispossessive settler-colonialism, further raises the question of whether giving up the transnational diasporic Jewish right of return is a prerequisite for decolonisation. Should Jewish return be suspended temporarily while the 
Palestinian refugee return is implemented? Or should the Law of Return ${ }^{\mathrm{vi}}$ be suspended permanently? In fact, would the Jewish Diaspora have a right to 'return' and consider Palestine-Israel as their 'national homeland' if decolonisation succeeds? These questions require a consideration of the nature of Jewish-Israeliness, its relationship to Palestine-Israel, and the wider Jewish Diaspora, and consequently their right to national self-determination in Palestine-Israel. In many respects, these questions are fundamental to the process of decolonisation, yet have no easy answers.

The necessity to rearticulate Jewish Israeliness as non-dominating is at the centre of the possibility for decolonisation. However, an emphasis on disavowal and self-negation is neither just nor practical for building co-resistance and working towards an egalitarian and just resolution to the ongoing settler-colonial apartheid. For, as Laila Farsakh (2011) writes, presently 'Most of the Palestinian debate on the one-state solution, while inclusive of Jews, avoids engaging with the complexity of Jewish identity and history. It clearly repudiates Zionism, but seeks to incorporate the Jewish person as a neutral repentant entity' (2011:70). She calls on Palestinian advocates of the one-state solution to build alliances with critical anti-Zionist Israelis and to initiate and conduct:

an open discussion on identity and a free open space to understand Israeli culture in its Western dimensions as much as in its Arab roots which it often negates...The second debate that needs to take place is about multiculturalism in Israel as well as in the Arab world and within Palestinian society, and how to reinvigorate the present Arab identity with the cosmopolitan character it once had (2011: 70).

This is indeed a pertinent task that needs to be undertaken by critical scholars and activists, particularly in light of growing transnational post-nationalist interconnections across the Arab world and beyond since the uprisings of January 2011. Sadly, the remainder of this paper 
cannot do justice to this rich and complex topic. Rather, the primary concern here is to engage with contemporary re-articulations of Israeli Jewishness or Jewish Israeliness in relation to the process of decolonisation, seeking to raise a number of issues for further discussion and engagement. In this respect, the critical commentary that follows is not intended as a prescription for a future identitarian category, rather it is an attempt to articulate alternative formulations of Jewish Israeli identification and the possibility for its decolonisation.

My suggested reading of Jewish Israeliness draws on a number of existing civil society alternatives to ICAHD's insistence on political Jewish self-determination in Palestine-Israel. These alternatives have in particular been articulated by activists working with Zochrot and, to a lesser extent, Anarchists Against the Wall. For the latter organisation, decolonisation is a process involving active resistance to, and the dismantling of, the apparatuses of occupation and colonisation, while largely avoiding identitarian debates. However, this has led to accusations that participation by critical Israelis in practical co-resistance activities reinforces a framing of anti-occupation activism as international solidarity activism in what is primarily a Palestinian national liberation struggle. Such reservations are, to a large extent, shortsighted and unwarranted, and both Marcel Svirsky (2010, 2014) and Uri Gordon (2008) address them robustly in their work. Svirsky, in particular, sees co-resistance and the refusal to engage in identitarian politics as an articulative practice which attempts to bring about in the present new modes of cohabitation while working towards ultimate decolonisation.

Zochrot activists similarly see decolonisation as an internal process which has to take place within the Jewish Israeli community, beginning with learning about and acknowledging that Palestinian dispossession is not only Palestinian history but also Jewish Israeli history, and then working towards the implementation of the right of the refugees to return. These 
attempts to conceptualise the Jewish settler community in Palestine-Israel in terms of an established Hebrew-speaking national community provide a useful alternative conceptualisation of Jewish Israeli self-determination (Musih and Bronstein, 2010). Their suggested form of self-determination in a shared state is socio-cultural rather than geopolitical in nature, and bears similarities to movements for cultural devolution in Europe, an example of this being Wales in the United Kingdom where Welsh national self-determination is embodied in the revival and practice of the Welsh language and cultural production, rather than a demand for ruling over a distinct ethno-national space. This model stands in contrast to the ethno-nationalist co-governance model represented by Belgium which ICAHD's binational statement draws upon; a model which has been widely criticised for reinforcing the very ethno-national segregation it was meant to combat.

\section{Reframing Belonging}

The above formulation requires further engagement with my chosen emphasis on identifying the settler collectivity as Jewish Israeli and the significance of this strategy. While I subscribe to secular democratic principles of citizenship, the strategic use of this label is first and foremost an attempt to acknowledge the significance of identitarian politics in PalestineIsrael in the present, while attempting a critical examination and suggesting a possible reframing, which in turn calls for further consideration. With good intentions, many Palestinians and critical Israelis prefer to place emphasis on the 'Jewish' dimension as the redeemable ethno-religious category in a context of decolonisation (for example, Uri Davis's 'Palestinian Jew', ICAHD's bi-national statement, the pre-Oslo PLO charter, etc.). From this perspective, the 'Israeli' component is considered to be imbued with the characteristics of Zionism and colonialism, and moreover implies acceptance of the Zionist settler-colonial project of the state of Israel, whereas the 'Jewish' harks back to an idealised vision of multidenominational coexistence before the Zionist settler-colonisation of Palestine-Israel. 
Both of these assumptions are deeply flawed, and serve to reinforce Zionism's own logic of settler-colonial supremacy. Above all, Israel is not an 'Israeli' state, as Abunimah and Barghouti correctly point out; it is a Jewish-dominated state that happens to be called Israel. In fact, the Zionist settler-colonial project seeks exclusive ethno-religious transnational diasporic Jewish self-determination in Palestine-Israel (Zreik, 2008) and the proposed 2014 'nation-state' Knesset bill adds further credence to this analysis. Thus, treating the 'Jewish' component as the neutral term of the Jewish-Israeli dyad merely obscures the role played by the Zionist conceptualisation of 'Jewishness' in its settler-colonial endeavour. One could argue, as Judith Butler (2012) does, that for this very reason Jewishness needs to be reclaimed from its Zionist conceptualisation. As such, anyone interested in unpacking and challenging the Zionist policy of dispossession in Palestine-Israel needs to examine the role of Jewishness in this settler-colonial project in a critical and conscious manner, acknowledging the function of the concept in the Zionist project, without dismissing or denying the fact that Jewishness means many different things around the world and is experienced in many different ways by different people who have defined themselves as Jewish historically or contemporarily.

An emphasis on Jewishness, which also then results in debates over ethno-religious Jewish rights to self-determination in Palestine-Israel, implies that Jews everywhere in the world have the right to settle and claim collective rights in Palestine-Israel by virtue of being Jewish. The above notion of collective transnational Jewish self-determination in PalestineIsrael is the premise of Zionism and the practice of the state of Israel as it stands under the Law of Return. However, what needs to be considered is whether, in a decolonised and postZionist Palestine-Israel, in the twenty-first century, after decades of anti-colonial struggle across the world, a notion of transnational collective Jewish right in/over Palestine-Israel can still be justified. Furthermore, in full agreement with Abunimah and Barghouti on their 
insistence on a secular democratic formulation, conceptualising rights in terms of ethnoreligious and sectarian groupings is itself highly problematic and threatens to recreate a new version of segregation, perhaps akin to the set-up characterising contemporary Lebanon, a set-up which contains the constant threat of inter-communal violence, something that a future decolonised Palestine-Israel would need to avoid.

Despite its violent and oppressive history, and the continuing violence, the notion of 'Jewish Israeli' is also, arguably, the concept that best encapsulates, for the time-being, the selfdefined ethno/religious Jewish and/or Hebrew-speaking people who have lived in PalestineIsrael for the past sixty-five to a hundred years. In that sense, 'Jewish Israeli' or even 'Israeli', as a potentially secular category, could function in much the same way as the 'Afrikaner' identity functions in post-Apartheid South Africa. Thus, although at present 'Israeli' carries the connotation of violence and dispossession by association with belonging to the Israeli settler-colonial state, in a post-apartheid situation it has the potential of becoming a cultural and not a political signifier. Over time, Israeli Jewishness has the potential of being re-articulated as a civic identity, allowing for Jewishness to be reclaimed as an ethno-religious and/or cultural self-identification rather than the racialised category it signifies in the current settler-colonial state of Israel. It also helps to avert the rather problematic attempt by some to reduce Jewishness to religion and religious practice, an attempt which denies the significance of the multiple ways in which Jewish self-identification has developed over the past two centuries.

In addition to drawing attention to the need to unpack and engage with the inherent tension between the 'Jewish' and 'Israeli' components in contemporary Jewish Israeli identification and its potential for decolonisation, the above formulation also requires further engagement with another significant aspect in relation to Palestine-Israel. Namely, the diasporic and/or 
transnational nature of the two national collectivities, which further complicates questions of self-determination within Palestine-Israel, not least because both populations can claim belonging, even if not indigeneity. To begin with, it is paramount that some of the more unique aspects and particularities of the Palestine-Israel situation be acknowledged in order to examine possibilities for decolonisation in a way that is constructive and involves the least amount of symbolic and/or real violence towards the indigenous and established settler communities in Palestine-Israel.

Palestine-Israel is not only a state created and settled by a transnational population with claims to diasporic origins in Palestine-Israel (see Sand, 2009 for a critical perspective on the origins of the Jewish diaspora) but, moreover, the creation of the Jewish settler-colonial state, in the process of expelling the majority of the indigenous Palestinian population in 1948, has in turn resulted in the birth of one of the largest Diasporas in the world. Currently, nearly half of all Palestinians live in the Diaspora, with many never having been allowed to visit and/or return to Palestine-Israel, and might not be permitted to do so in their lifetime. This makes the geo-political dimensions of the conflict and any rights-based claims transnational and extraterritorial in a way that is not comparable to any other contemporary situation. For this reason, claims and counter claims to indigeneity and exogeneity, justice in, and rights in and to the land of Palestine-Israel need to be carefully unpacked and considered in relation to actual and lived realities as well as aspirations for a just future.

An appeal to an inclusive politics of belonging can perhaps offer a better solution to the problem of securing decolonial cohabitation between settled Jewish Israelis and the Palestinian people. An inclusive politics of belonging would build on the notion of 'belonging' as defined by embodied spatial and geopolitical configurations (Trudeau, 2006), and individuals' and groups' location in relation to and in association with others who are similarly located (Carrilo Rowe, 2005). As Probyn (1996: 19) argues, belonging, as opposed 
to identity, 'captures more accurately the desire for some sort of attachment, be it to other people, places, or modes of being, and ways in which individuals and groups are caught within wanting to belong, wanting to become, a process that is fuelled by yearning rather than a position of identity as a stable state'. Such a notion highlights the centrality and potential of building on a shared attachment to place, and the identification of the geographical space of Palestine-Israel as 'home' for both the indigenous and settler collectivities.

While the politics of belonging presupposes a notion of belonging as emotional attachment to place, belonging and the politics of belonging are nevertheless two separate but related concepts (Antonsich, 2010). Drawing on the work of Yuval-Davis $(2006,2011)$ this paper calls for the need to articulate an inclusive politics of belonging that goes beyond legalistic and ethno-centric interpretations of the right to self-determination, and seeks instead to centre the notion of 'home' as opposed to 'homeland' in thinking through post/decolonial cohabitation. What I mean by this is that there is a need to consider established Jewish Israeli settlers as belonging in Palestine-Israel by virtue of their sense of emotional attachment to the place, and therefore as having the right to actualise themselves as individuals and as a cultural collectivity in a decolonial and non-dominating way. This type of an inclusive politics of belonging equally applies to the right to belong for non-colonial migrant settlers, echoing the sentiment of No One is Illegal that "everyone who is here belongs here" (see Walia, 2013); that is, so long as they remain committed to decolonial forms of association and cohabitation that reject domination and oppression.

Thus, while Abunimah $(2010 ; 2012)$ is correct in arguing that in the present the principle of self-determination only applies to indigenous and/or minority ethnic groups, nevertheless some form of acknowledgement of collective identification among Jewish Israelis has to take place given the long history of conflict and the undeniable presence of two national groups which are strongly defined and established along ethno-national lines, at least at the present 
time. An acknowledgement of, and a more concerted critical engagement with, the rights claims of Jewish Israelis would further serve to alleviate the fears of expulsion in the eventuality of decolonisation, fears also shared by some critical Israelis. An example of this is Jeff Halper's (2013) response to Abunimah and Barghouti's critique of ICAHD's 2012 binational proposal where he argues that the position that Jewish Israelis have no right to selfdetermination in Palestine-Israel

\begin{abstract}
'shared though not usually articulated so clearly by many of the Palestinian left, begins to resemble the position of Hamas (or, inversely, the settlers), based though it is on anti-colonial indigenous rights rather than religion. It leaves unclear the civil status of Israelis/Jews in this one democratic but not bi-national state. At best, this would lead to an ethnocracy comparable to Israel today, with Israeli Jews possessing the unacceptable civil status suffered by "Israeli Arabs" today. Or it might take the form of Zimbabwe, where a European minority was allowed to stay but ended up with limited civil rights, or even an Algeria where the French settler colonialists were forced to leave immediately upon liberation. In short, crucial issues of collective rights in a single state have been left deliberately vague'
\end{abstract}

Although the above sentiment can be critiqued for misreading Abunimah and Barghouti's rejection of Jewish self-determination as primarily a rejection of an extra-territorial Jewish right to settler-colonisation of Palestine-Israel, it is nevertheless not only a call for an acknowledgement of Jewish Israeli identity, but more so a request for affirmation of the right to remain and culturally self-determine in the process of decolonisation. An acknowledgement of this concern can further serve to encourage currently inactive Jewish Israelis to join and play an active part in the struggle for decolonisation. Though, naturally, 
egalitarian and democratic cohabitation would require that in the long-run nationalistic identifications gradually yield to other more civic minded forms of belonging.

Conversely, as an acknowledgement of the historical and ongoing injustice perpetrated against the Palestinian people, decolonisation in Palestine-Israel would require an end to geopolitical claims to self-determination in Palestine-Israel by transnational Jewish communities. Thus, the return to the homeland will remain the prerogative of the Palestinian refugee diaspora, while non-Israeli Jewish individuals and communities who might wish to migrate to Palestine-Israel would become subject to open and fair migration procedures in the same way as all other exogenous individuals and collectivities wishing to reside in Palestine-Israel (Oren Yiftachel, 2010, makes a similar proposal). Therefore, an end to a transnational right to Jewish settlerism in Palestine-Israel must accompany the geo-political and psycho-social decolonisation of the land and its people, allowing for the indigenous and established settler communities to formulate and articulate new forms of cohabitation and identification.

\section{Conclusion}

The above considerations of Jewish Israeli identification in relation to belonging, binationalism and self-determination in Palestine-Israel acknowledge the validity of ICAHD's bi-national position, in as far as it is a recognition of the recurrent ethno-centric set-up in Palestine-Israel. In light of criticisms from Palestinian counterparts, when examined from the perspective of the all-affected, particularly taking into account the rights of the dispossessed and disenfranchised Palestinian Diaspora, Jewish political self-determination in a decolonised Palestine-Israel appears unjust and deeply problematic. However, an alternative to ICAHD's bi-nationalism is offered in the conceptualisation of bi-national cohabitation as cultural selfdetermination. 
The unprecedented convergence between critical Palestinian and Israeli thought in relation to the necessity to rearticulate the situation in Palestine-Israel as one of settler-colonialism and to work towards the possibility for decolonisation is the by-product of the failures of the official peace process. While the resulting advocacy for cohabitation in a single democratic state, signalling a move away from the discourse of ethno-national separation embodied in the two-state solution paradigm, is to be welcomed, it is, nevertheless, important to remain cautiously optimistic. At present, the role played by critical Israeli groups such as Zochrot, AATW, Boycott from Within, and ICAHD, in terms of challenging the dominant framing of Zionist settler-colonialism, is significant but remains a minority position both within the transnational movement for just peace and within Jewish Israeli society.

What these groups highlight is the possibility for critical engagement and convergence between Palestinian and Israeli interests towards peaceful cohabitation, but also the necessity to expand the terrain for contestation and engagement with and within Jewish Israeli society. As such, critical responses by Palestinian counterparts must address the anxieties expressed and felt by many Israelis in relation to the possibility of decolonisation. The question raised by ICAHD's bi-national statement and Jeff Halper's subsequent response to Palestinian criticisms is primarily a request for reassurance that there will be a place for Jewish Israelis in a decolonised Palestine-Israel. This is perhaps something the BDS movement, particularly its Palestinian leadership, might wish to address. The ANC strategy of reaching out to the Afrikaaner community during the anti-apartheid struggle might be a place to draw inspiration from. Alternatives are also present in similar situations such as Aotearoa New Zealand (see Bell, 2009). However, at the same time it is important for critical Israelis to remain cognisant of the privileged and relatively powerful position in which their identity has been constructed to date, the necessary deconstruction of which is a precondition for decolonisation. 
The above considerations seek to highlight the importance of acknowledging and thinking through questions of identity and belonging as part of the cultural and symbolic process of decolonisation. At the same time, the principle of the 'all affected', which underpins the framework of this paper, foregrounds cohabitation/reconciliation as a relation of justice and a commitment to justice which necessitates a critical reframing and rearticulation of the classed, gendered and racialised structures which maintain settler-colonialism and the injustices it represents. A combination of these critical approaches is necessary, not only in thinking about a just solution to Palestinian and Jewish Israeli cohabitation, but also in thinking beyond the bi-national binary, and moving to address the needs of all citizens irrespective of their ethno-national affiliations. In the words of Harsha Walia (2013: 249):

'Decolonisation is more than a struggle against power and control; it is also the imagining and generating of alternative institutions and relations... [It] requires a fundamental reorientation of ourselves, our movements, and our communities to think and act with intentionality, creativity, militancy, humility, and above all, a deep sense of responsibility and reciprocity’.

\section{Endnotes}

\footnotetext{
${ }^{i}$ The Nakba refers to the catastrophic events of 1947-9 during which the majority of the Palestinian population was displaced in the wake of the establishment of the state of Israel.

ii Article 49 of the Fourth Geneva Convention stipulates: 'Individual or mass forcible transfers, as well as deportations of protected persons from occupied territory to the territory of the Occupying Power or to that of any other country, occupied or not, are prohibited, regardless of their motive... The Occupying Power shall not deport or transfer parts of its own civilian population into the territory it occupies'.

iii This refers to the settler-colonial tendency to eliminate or exterminate the indigenous population in the process of establishing its claim to the land in order to govern unchallenged (Wolf, 2006; Veracini, 2010).

${ }_{\text {iv }}$ This stand-point is greatly indebted to the work of Hannah Arendt (1951, 1958, 1970, 2007), and David Harvey (2009).

${ }^{v}$ See Gordon, N. (2013) for the Israeli High Court Ruling against a petition for Israeli nationality.

vi The Law of Return (1950) makes it possible for every person defined as Jewish, anywhere in the world, to make aliyah, literally meaning 'ascent', to Israel and be granted automatic citizenship upon arrival in Israel.
}

\section{References}


Abunimah, Ali (2006) One Country: A Bold Proposal to End the Israeli-Palestinian Impasse, New York: Metropolitan Books.

Abunimah, Ali (2010) 'Reclaiming self-determination', Al-Shabaka Policy Brief, http://alshabaka.org/policy-brief/politics/reclaiming-self-determination, accessed 14.11.2012.

Abunimah, Ali (2012) 'ICAHD endorses one-state solution, warns against "warehousing" of Palestinians' in The Electronic Intifada, http://electronicintifada.net/blogs/aliabunimah/icahd-endorses-one-state-solution-warns-against-warehousing-palestinians, accessed 14.11.2012.

Abu Zahra, Nadia (2008) 'IDs and Territory: Population Control for Resource Expropriation' in Cohen, Deborah and Gilbert, Emily, eds., War, Citizenship, Territory, New York: Routledge.

Aharonson, Ran (1996) "Settlement in Eretz Israel - A Colonialist Enterprise? "Critical" Scholarship and Historical Geography’ in Israel Studies, Vol. 1, No. 2, pp. 214-229.

Aljazeera Middle East (2012) 'UN votes to upgrade Palestinian status' in Aljazeera, http://www.aljazeera.com/news/middleeast/2012/11/20121128142545792986.html, accessed 30.11.2012

Antonsich, M. (2010) 'Searching for Belonging - An Analytical Framework', in Geography Compass, Vol. 4, No. 6, pp. 644-659.

Arendt, Hannah (1951) The Origins of Totalitarianisms, New York: Schocken Books.

Arendt, Hannah (1958) The Human Condition, London: University of Chicago Press.

Arendt, Hannah (1970) On Violence, London: Penguin Press.

Arendt, Hannah (2007) The Jewish Writings, Kohn, Jerome and Feldman, Ron H., eds., New York: Schocken Books.

Atran, Scot (2010) Talking to the Enemy: Violent Extremism, Sacred Values, and What it Means to be Human, London: Allen Lane.

Azoulay, Arialla and Adi Ophir (2012) The One-State Condition - Occupation and Democracy in Israel/Palestine, Stanford: Stanford University Press.

Barghouti, Omar (2011) Boycott, Divestment, Sanctions: The Global Struggle for Palestinian Rights, London: Haymarket Books

Barghouti Omar (2012) 'A Secular Democratic State in Historic Palestine: Self-Determination through Ethical Decolonisation' in Loewenstein, Antony and Moor, Ahmed eds., After Zionism: One State for Israel and Palestine, London: Saqi Books.

Barghouti, Omar (2014) 'Opting for justice: the critical role of anti-colonial Israelis in the boycott, divestment, and sanctions movement' in Settler Colonial Studies, Vol. 4. No. 4., pp. 407-412.

Bisharat, George E. (2008) "Maximizing Rights: The One State Solution to the PalestinianIsraeli Conflict," Global Jurist, Vol. 8, No. 2 (Frontiers), Article 1, pp. 1-36. 
BDS Movement (2005) 'Palestinian Civil Society Call for BDS', http://www.bdsmovement.net/call, accessed 5.4.2009.

Bell, A. (2009) 'Dilemmas of settler belonging: roots, routes and redemption in New Zealand national identity claims' in The Sociological Review, Vol. 57, No. 1, pp. $145-162$.

Butler, Judith (2012) Parting Ways: Jewishness and the Critique of Zionism, New York: Columbia University Press.

Carrillo Rowe, A. (2005) 'Be longing: Toward a feminist politics of relation' in NWSA Journal, Vol. 17, No. 2, pp. 15-37.

Cocks, Joan (2006) 'Jewish Nationalism and the Question of Palestine' in Interventions: International Journal of Post-colonial Study, Vol. 8. No. 1, pp. 24 - 39.

Davis, Uri ([1987] 1990) Israel, an Apartheid State, London: Zed Books.

Davis, Uri (2003) Apartheid Israel: Possibilities for the Struggle Within, London: Zed Books.

Davis, Uri (2010) 'Naming the Coloniser in Geographic Palestine: Conceptual and Political Double Binds and their Possible Solutions' in Hilal, Jamil and Pappe, Ilan, eds., Across the Wall: Narratives of Israeli-Palestinian History, London: I.B. Taurus.

Eldar, Akiva and Zertal, Idith (2007) Lords of the Land: The War Over Israel's Settlements in the Occupied Territories, 1967-2007, New York: Nation Books.

Elkins, Caroline and Pedersen, Susan, eds. (2005) Settler Colonialism in the Twentieth Century, London: Routledge.

Elkins, Caroline (2005) 'Race, Citizenship, and Governance: Settler Tyranny and the end of Empire' in Settler Colonialism in the Twentieth Century, Elkins and Pedersen, eds., London: Routledge.

Falah, Ghazi-Walid (2004) 'Truth at War and Naming the Intolerable in Palestine' in Antipode: A Radical Journal of Geography, Vol. 42, No.2, pp. 310-335.

Farsakh, Laila (2011) 'The One-State Solution and the Israeli-Palestinian Conflict: Palestinian Challenges and Prospects' in Middle Eastern Journal, Vol.65, No. 1, pp. 55-71.

Fraser, Nancy (2005) 'Reframing Justice in a Globalizing World' in New Left Review, Vol. 36 , pp. $69-88$.

Fraser, Nancy (2008) Scales of Justice: Re-imagining Political Space in a Globalizing World, Cambridge: Polity.

Ghanim, Honaida (2008) 'Thanatopolitics: The Case of the Colonial Occupation of Palestine' in Lentin, Ronit, ed., Thinking Palestine, London: Zed Books.

Goldstein, Aloysha and Lubin, Alex, eds. (2008) Settler colonialism, Durham N. C.: Duke University Press.

Gordon, Neve (2008) 'From Colonisation to Separation: exploring the structure of Israel's Occupation' in Third World Quarterly, Vol. 29, No. 1, pp. 25 - 44. 
Gordon, Neve (2013) 'High court rules: It is impossible to be Israeli' in Al Jazeera English, http://www.aljazeera.com/indepth/opinion/2013/10/high-court-rules-it-impossible-beisraeli-201310201360824801.html; accessed 25.04.2014.

Gordon, Uri (2008) Anarchy Alive! Anti-Authoritarian Politics from Practice to Theory, London: Pluto.

Gordon, Uri and Grietzer, Ohal, eds. (2013) Anarchists Against the Wall, Oakland: AK Press.

Gregory, Derek (2004a) The Colonial Present: Afghanistan, Palestine, Iraq, Oxford: Blackwell Publishing.

Gregory, Derek (2004b) 'Palestine Under Siege' in Antipode: A Radical Journal of Geography, Vol. 36, No. 3, pp. 601- 606.

Halper, Jeff ([2008] 2010) An Israeli in Palestine: Resisting Dispossession, Redeeming Israel, London: Pluto Press.

Halper, Jeff (2012) 'Beyond Regional Peace to Global Reality' in Loewenstein, Antony and Moor, Ahmed eds., After Zionism: One State for Israel and Palestine, London: Saqi Books.

Halper, Jeff (2013) 'Towards an end-game in Palestine - Israel - While imagining the future', http://www.icahd.org/node/486, accessed 05.02.2014.

Hanafi, Sari (2009) 'Spacio-cide: colonial politics, invisibility and rezoning in Palestinian Territory' in Contemporary Arab Affairs, Vol. 2, No. 1, pp. 106-121.

Harvey, David (2009) Cosmopolitanism and the Geographies of Freedom, Columbia: Columbia University Press.

Hermann, Tamar (2005) 'The bi-national idea in Israel/Palestine: past and present' in Nations and Nationalism, Vol. 11, No. 3, pp. $381-401$.

Hilal, Jamal, ed. (2007) Where Now for Palestine? The Demise of the Two-State Solution, London: Zed Books.

ICAHD (2012) 'In the Name of Justice: ICAHD Raises Key Issues Around a Single State as a Step Towards Resolving the Israeli-Palestinian Conflict', http://www.icahd.org/node/423, accessed 25.09.2012.

Kamel, Lorenzo (2014) 'Overcoming Post-colonialism in the Eastern Mediterranean', presentation at the BRISMES Annual Conference, Brighton.

Karsh, Efraim, ed., (2012) 'Special Issue: War by other means, Israel and its detractors' in Israel Affairs, Vol. 18, No. 3, pp. 319-501.

Khalidi, Rashid (1997) Palestinian identity: the construction of modern national consciousness; Chichester: Columbia University Press.

Khalidi, Rashid (2006) The Iron Cage: The Story of the Palestinian Struggle for Statehood, Oxford: Oneworld. 
Lis, Jonathan (2014) 'Netanyahu's cabinet approves controversial bill enshrining Israel as 'Jewish nation-state'' in Ha'aretz, http://www.haaretz.com/news/national/1.628001.

Little, David (2006) 'Peace, Justice and Religion' in Allan, Pierre and Keller, Alexis, eds., What is Just Peace?, New York: Oxford University Press. Lloyd, David (2012) 'Settler Colonialism and the State of Exception: The Example of Palestine/Israel' in Settler Colonial Studies, Vol. 2, No. 1, pp. $59-80$.

Loewenstein, Antony and Moor, Ahmed eds. (2012) After Zionism: One State for Israel and Palestine, London: Saqi Books.

Long, Joanna C. (2006) 'Border Anxiety in Palestine-Israel' in Antipode: A Radical Journal of Geography, Vol. 38, No 1, pp. 107-127.

Mansdorf, Irwin J. (2010) 'Is Israel a Colonial State? The Political Psychology of Palestinian Nomenclature', Jerusalem Centre for Public Affairs, No. 576, http://jcpa.org/article/isisrael-a-colonial-state-the-political-psychology-of-palestinian-nomenclature/.

Mavroudi, Elizabeth (2010) 'Imagining a Shared State in Palestine-Israel' in Antipode: A Radical Journal of Geography, Vol. 42, No 1, pp. 152-178.

Musih, Norma and Bronstein, Eitan (2010) 'Thinking Practically about the Return of the Palestinian Refugees' in Sedek: a Journal on the ongoing Nakba.

Pappé, Ilan (2006) The ethnic cleansing of Palestine; Oxford: Oneworld.

Pappé, Ilan (2008) 'Zionism as Colonialism: A Comparative View of Diluted Colonialism in Asia and Africa' in The South Atlantic Quarterly, Vol. 107, No. 4, pp. 611 - 633.

Pappé, Ilan (2011) The Forgotten Palestinians: A History of the Palestinians in Israel, London: Yale University Press.

Pappé, Ilan (forthcoming) People's Apart: Israel, South Africa, and the Apartheid Question, London: I.B. Taurus.

Pedersen, Susan (2005) 'Settler Colonialism at the Bar of the League of Nations' in Settler Colonialism in the Twentieth Century, Elkins and Pedersen, eds., London: Routledge.

Peled-Elhanan, Nurit (2012) Palestine in Israeli School Books: Ideology and Propaganda in Education, London: I.B. Taurus.

Piterberg, Gabriel (1996) 'Domestic Orientalism: The Representation of "Oriental" Jews in Zionist/Israeli Historiography' in British Journal of Middle Eastern Studies, Vol. 23, No. 2, pp. $125-145$.

Piterberg, Gabriel (2001) 'Erasures' in New Left Review, No. 10, pp. 31-46.

Piterberg, Gabriel (2008) The Returns of Zionism: Myths, Politics and Scholarship in Israel, London: Verso.

Piterberg, Gabriel (2010) 'Settlers and their States: A Reply to Zeev Sternhell' in New Left Review, No. 62, pp. $115-123$

Probyn, Elspeth (1996) Outside belonging, London: Routledge. 
Qumsiyeh, Mazin, B. (2010) Popular Resistance in Palestine: A History of Hope and Empowerment, London: Pluto Press.

Raz-Krakotzkin, Amnon (2011) 'Exile and Binationalism - From Gershom Scholem to Hannah Arendt to Edward Said and Mahmoud Darwish', Carl Heinrich Becker lecture.

Said, Edward W. (1984) 'Permission to Narrate' in Journal of Palestine Studies, Vol. 13, No. 3, pp. 27-48.

Said, Edward W. (1988) 'Identity, Negation and Violence' in New Left Review, No. 171, pp. $46-60$.

Said, Edward W. (2000) Reflections on Exile and Other Literary and Cultural Essays, London: Granta.

Said, E., W., (2004) From Oslo to Iraq and the Roadmap, London: Bloomsbury.

Said, Edward W. (2006) 'A Method for thinking about Just Peace' in Allan, P., and Keller, A., eds, What is Just Peace?, New York: Oxford University Press.

Said, Edward W. (2010) 'Invention, Memory, Place', in Critical Inquiry, Vol. 26, No. 2, pp. 175-192.

Shafir, Gershon (2005) 'Settler Citizenship in the Jewish Colonisation of Palestine' in Elkins and Pedersen, eds., Settler Colonialism in the Twentieth Century, London: Routledge.

Sand, Schlomo (2009) The Invention of the Jewish People, London: Verso

Smith, Andrea (2010) 'Indigeneity, Settler Colonialism, White Supremacy' in Global Dialogue, Vol. 12, No. 2.

Stasiulis, Daiva and Yuval-Davis Nira, eds., (1995) Unsettling Settler Societies: Articulations of Gender, Race, Ethnicity and Class, London: Sage.

Svirsky, Marcelo (2012) Arab-Jewish Activism in Israel-Palestine, Farnham: Ashgate.

Svirsky, Marcelo (2014a) 'The collaborative struggle and the permeability of settler colonialism' in Settler Colonialism, Vol. 4, No. 4, pp. 327-332.

Svirsky, Marcelo (2014b) 'On the study of collaborative struggles in settler societies' in Settler Colonial Studies, Vol. 4, No. 4, pp. 434-449.

Tharoor, Ishaan (2014) 'Map: The countries that recognize Palestine as a state' in The Washington Post, http://www.washingtonpost.com/blogs/worldviews/wp/2014/11/07/map-the-countriesthat-recognize-palestine-as-a-state/, accessed 15.11.2014.

Tilly, Virginia (2005) The One State Solution: A Breakthrough for Peace in the Israeli Palestinian Deadlock, Manchester: Manchester University Press.

Trudeau, Daniel (2006) 'Politics of belonging in the construction of landscapes: placemaking, boundary-drawing and exclusion' in Cultural Geographies, Vol. 13, No. 3, pp. $421-443$. 
United Nations Security Council Resolution 242 (1967), http://unispal.un.org/unispal.nsf/0/7D35E1F729DF491C85256EE700686136, accessed 14.11.2011.

Veracini, Lorenzo (2007) 'Settler Colonialism and Decolonisation' in Borderlands, Vol. 6, No. 2.

Veracini, Lorenzo (2010) Settler Colonialism: a theoretical overview, London: Palgrave Macmillan.

Walia, Harsha (2013) Undoing Border Imperialism, Edinburgh: AK Press.

Weizman, Eyal (2007) Hollow Land: Israel's Architecture of Occupation, London: Verso.

Weizman, Eyal (2011) The Least of All Possible Evils: Humanitarian Violence from Arendt to Gaza, London: Verso.

Wolfe, Patrick (1999) Settler colonialism and the transformation of anthropology: the politics and poetics of an ethnographic event, London: Cassell.

Wolfe, Patrick (2006) 'Settler Colonialism and the Elimination of the Native' in Journal of Genocide Research, Vol. 8, pp. 387-410.

Yiftachel, Oren (2010) 'Ethnocracy': The Politics of Judaizing Israel/Palestine' in Pappé, Ilan and Hilal, Jamil, eds. , Across The Wall: Narratives of Israeli-Palestinian History, London: I.B. Taurus.

Young, Iris Marion (2007) Global Challenges: War, Self-Determination, and Responsibility for Justice, Cambridge: Polity Press.

Yuval-Davis, Nira (2006) 'Belonging and the politics of belonging' in Patterns of Prejudice, Vol. 40, No. 3, pp. 197-214.

Yuval-Davis, Nira (2011) The Politics of Belonging: Intersectional Contestations, London: Sage.

Zreik, Raef (2008) 'The Resistance of the Exception: Some remarks on the story of Israeli Constitutionalism', in Lentin, Ronit, ed., Thinking Palestine, London: Zed Books. 